\title{
Bayer Corneal Epitheliopathy Grade 2
}

National Cancer Institute

\section{Source}

National Cancer Institute. Bayer Corneal Epitheliopathy Grade 2. NCI Thesaurus. Code C128442.

Epithelial opacities; micro-cysts; micro-deposits; corneal erosion; non-central stromal opacity. 